\title{
Water Quality Standards in Private
}

\section{Nuisance Actions}

After Austin flushed its storm sewers in 1961, seventy tons of dead fish were strewn along the banks of the river below. ${ }^{1}$ In the eight years since, our rivers have become no healthier; so polluted with oil and chemicals that it cannot support even the lowliest sludge worm, the Cuyahoga River burst into flames last summer and nearly destroyed two railroad bridges. ${ }^{2}$

Blunted by bureaucratic timidity and deference to industry, the Federal Water Quality $\mathrm{Act}^{3}$ and various state anti-pollution statutes ${ }^{4}$ have proved ineffective. This Note will suggest, however, that a secondary effect of the recent Federal Act may be to revivify private nuisance actions, ${ }^{5}$ and thus to help restore the quality of our water.

\section{I. "Reasonable Use" as a Defendant's Rule}

The basis of a nuisance action is that unreasonable use by the defendant has caused unreasonable harm to the plaintiff. ${ }^{0}$ Uncler the

1. R. Garson, Silent Spring 145 (1962).

2. Tinre, Aug. 1, 1969, at 41 .

3. Water Quality Act of 1965 , Pub. L. No. 89-234, 79 Stat. 903, enacting 33 U.S.C. \$ $866-1$ and $466 \mathrm{c}-1$ and amending 33 U.S.C. \$\$ 466,d,e,g,h,i (1964) (codificd at 33 U.S.C. $\S \S 466-466 \mathrm{k}$ (Supp. IV 1969)). This Act established water quality standards; it wats onc of a number of amendments to the basic Federal pollution legislation, the Fed. Water Pollution Control Act of 1948, ch. 758, 62 Stat. 1155.

4. The most complete catalogue of state actions to establish water quality standards and/or stream classification appears in Hearings on 5.649 Before the Stubomm. on Air and Water Pollution of the Senate Pub. Works Comm., 88th Cong., 1st Scss. at 119.22 (1963). At the time of these hearings thirty-six states had enabling legislation; twenty.two states had acted upon that legislation. Depending upon the peculiarities of the statutes involved, the arguments advanced in this Note may be applicable to standards set pursuant to state statutes. But in this respect, see the limiting provision in N.Y. PUn. HEAL'tI LAW \$ 1261 (McKinney Supp. 1969):

The basis for proceedings or actions resulting from the violations of the prohibitions contained in this article inure solely to and are for the benefit of the pcople gencrally of the State of New York, and it is not intended to in any way create new, or enlarge existing rights of riparian owners or others. A determination by the water resources commission or the commissioner that pollution exists or that violations of any of the prohibitions in this article, whether or not a proceeding or action may be brought by the state, shall create by reason thereof no presumptions of law or findings of fact inuring to or for the benefit of persons other than the statc.

5. The legal literature has documented the failings of the private tort action. Sct, e.t., Hanks, The Law of Waters in New Jersey, 22 Rutcers L. Rev. 621, 668 (1968); Hincs, Nor Any Drop to Drink: Public Regulation of Water Quality, 52 IoWA L. REv. 186, 196.201 (1966); Note, Statutory Treatment of Industrial Stream Pollution, 24 Geo. WAst, L. Rtv. 302, 305-10 (1956).

6. I Harper \& James, The Law of TorTs, \& 1.24 at 71 (1956). Prosser takes the somewhat different position that nuisance "has reference to the interests invaded, to the damage or harm inflicted, and not to any particular kind of act or omission which has led to the invasion." Prosser, The LAW OF TORTS, § 88, at 594 (1964). 
riparian theory of water rights, which prevails in the eastern United States, ${ }^{7}$ every owner of property adjacent to a watercourse has a right to use the water which passes his property. According to the most widely accepted form of this theory, a riparian has the right to make reasonable use of the water subject to the similar right of all other riparians. ${ }^{8}$ Thus, the "reasonable use" form of the riparian theory of water rights fits conveniently into the format of the nuisance action: since both plaintiff and defendant have a right to reasonable use of the watercourse, the courts must ask the interrelated questions whether the defendant's pollution has exceeded reasonable use and whether the defendant's polluting activities have infringed upon the plaintiff's right to a reasonable use. ${ }^{9}$

In actual water rights cases, however, the courts have focused almost exclusively upon the social value of the defendant's conduct

7. [T] re riparian doctrine forms the primary basis of the Inv's gorerning the use of natural watercourses in most eastern states-that is, the 31 states lying cast of the tier from the Dakotas to Texas.

1 WATER AND WATER RIGHTS \& 19.1, at 83 (R. Clark ed. 1967).

The prior appropriation theory forms the basis of WVestern water law. In bricfest form the prior appropriation theory holds that water may be taken from a watercourse for any beneficial use and that priority in time creates priority in right. This theory primarily addresses the problem of water diversion rather than that of pollution. In its "Colorado" or strict form, Arizona, Colorado, Idaho, Montana, Neveda, New Mícxico, Utah and Wyoming adhere to this doctrine. Id. $\$ 39.2$. The line of analysis pursucd in this Note is not on point for those jurisdictions. But see Hines, supra note 5, at 196.97, suggesting that since the action is usually brought under the law of private nuisance, the standard does not vary with the theory of water rights employed by the particular state. The mixed systems in California, Kansas, Nebraska, North Dakota, Oklahoma, Oregon, South Dakota, Texas and Washington contain elements of the riparian doctrine. Consequently the analysis pursued here may have some application in several of those states. See $5 \mathrm{R}$. Powell, The LAw of ReAL ProperTy $99739-42$ (1968).

8. See Note, Stream Pollution-Recovery of Damages, 50 Iowa L. REv. 141, 142 (1961). The other form of riparian theory, "natural flow," provides that a riparian is entitied to the use of water undiminished in quantity or quality. Id. Courts frequently allude to "natural flow" but employ "reasonable use" as the actual test of the permissible limit of both diversion and pollution. Hanks, supra note 5, at 670-71. For a discussion of the extent to which various states have adopted "reasonable use," see R. Poweln, supra note 7, TI $711-12$.

9. The Restatement of Torts views the "reasonable use" test as a weighing of the utility of the defendant"s use against the gravity of the resulting harm. REsTateunest of TORTS $\$ 852$ (1999). Utility of the use should be measured by

(a) the social value which the law attaches to the primary purpose for which the use is made;

(b) the suitability of the use to the watercourse or lake, and to the customs and usages existing with respect to it;

(c) the impracticability of preventing or avoiding the harm; and

(d) the classification of the use as riparian or nonriparian.

Id. $\S 853$.

Gravity of the harm is measured by strikingly similar considerations:

(a) the extent of the harm involved;

(b) the social value which the law attaches to the particular type of use of water which is interfered with;

(c) the suitability of such use to the particular watercourse or lake;

(d) the burden on the proprietor harmed of avoiding the harm; and

Id. $\$ 854$. 
and upon the suitability of the defendant's activity to the watercourse. In the leading case of Pennsylvania Coal Co. v. Sanderson, ${ }^{10}$ for example, the defendant was admittedly discharging large quantities of acid from its mining operations into a stream. Nevertheless, the lower riparian who brought an action in nuisance was denied recovery. The court held that the defendlant was engaged in an activity beneficial to the commonwealth and that it might carry on mining activities as before. Although the court specifically left open the possibility that pollution might constitute a nuisance, the abatement of which might be required by the public interest in "the general health and well-being of the community,"11 the Sanderson opinion emphasizes the importance of the development of natural resources and the unfairness of holding the mining company accountable for "consequences which it could not control."12 The phrase "consequences which it could not control," of course, begs the question.

Under an improved version of the Sanderson doctrine, when a nuisance action is brought against someone engaged in a socially beneficial activity, the court must inquire into the standard practice within the appropriate industry to determine whether the defendant has acted reasonably. ${ }^{13}$ But by setting the standard according to what is, rather than what ought to be, the "industry practice" test still favors polluters unduly.

Yet a further improvement on the Sanderson doctrine would adjust the "industry practice" standard to reflect differences in the quality of individual watercourses. But the incremental process by which our rivers are destroyed minimizes the effectiveness of such control. Only in those rare instances in which pollution by one manufacturer creates a marked decline in water quality or in which pollution of a river is stopped at an early stage ${ }^{14}$ does the character of the watercourse avail as a limitation upon defendant's reasonable use. Gross pollution by other riparians becomes a justification for pollution by the riparian defendant, and "character of the watercourse" reduces to "indus-

10. 113 Pa. 126, 6 A. 453 (1886).

11. Id. at $149,6 \mathrm{~A}$. at 459 .

12. Id. at 147,6 A. at 457 .

13. See, e.g., Snow v. Parsons, 28 Vt. 459 (1856), where the court reversed and remanded a judgment for the plaintiff with instructions that the lower court accept testimony offered by the defendant tannery "on the usage in the country as to tanneries." Id. at 464.

14. Even at an early stage, the factor may be meaningless. In McDonough v. RussellMiller Milling Co., 38 N.D. 465,165 N.W. 504 (1917) the court reasoned that it ought not to arrest manufacturing by insisting upon pristine streams where there have been no previous users. 
try practice" with a slight twist. For example, a court under the influence of the Sanderson doctrine will find it impossible to recognize that the sum of actions by a number of polluters, each of which seems reasonable in its own right, may nonetheless create an invasion of a plaintiff's right to reasonable use of the watercourse.

The "industry practice" standard evolved at a time when manufacturers could pollute some rivers without depriving the people generally of the opportunity to use other rivers for recreation. But rapid industrialization has by now spread pollution to nearly all of our rivers. In consequence, the law must recognize that waste disposal can no longer be the only legitimate use of a river. However modified or refined, ${ }^{15}$ the Sanderson doctrine suffers from an essential weakness: its one-sided emphasis on the social benefits of the defendant's activity and on the suitability of that activity to the watercourse mocks the balancing process which is the theoretical basis of nuisance law. The courts should also measure the reasonableness of a defendant's use in terms of damage to the plaintiff because the quality of the water he receives is below that to which he is entitled as a riparian owner.

Even when accepting in theory that a plaintiff is entitled to have the character of the watercourse assessed from his orm perspective, courts have lacked a base line from which to judge the unreasonableness of his alleged harm. Unaided by legislation, the judicial process has demonstrably failed to determine the limit beyond which a watercourse may not be polluted; thus, the practical effect of the reasonable use test has been to slight the interests of the injured riparian and of the general public.

The Federal Water Quality Act ${ }^{\mathbf{1 6}}$ may finally have made possible effective recognition of the rights of the injured riparian. Under the procedure established by the Act for the setting of water quality standards on interstate watercourses, each state, subject to the approval of the Secretary of the Interior, adopts "water quality criteria applicable to interstate waters or portions thereof within such State" and "a plan for the implementation and enforcement of the water

15. While the Sanderson decision has been distinguished on the facts and while many courts have taken a more enlightened approach (see, e.g., Strobel v. Kerr Salt Co., 164 N.Y. 303,58 N.E. 142 (1900)), the negative impact of the Sanderson premises about resource use is reflected in the infrequency of private nuisance actions in the face of a general deterioration in water quality.

16. See note 3, supra. For the legislative history, sce 1965 U.S. ConE CoNc. \& ADM. NEWS 3313ff. 
quality criteria adopted. . .."17 The Secretary of the Interior has reached basic agreement with all states except Iowa. ${ }^{18}$

While the Federal Act is significant for its statement of public policy and for its comprehensive approach to the evaluation of pollution data, it suffers from a weak enforcement mechanism. ${ }^{10}$ Under the Act, the Secretary of the Interior "may request" that the Attorney General initiate a law suit against a polluter..$^{20}$ When the damage from pollution occurs in the same state as the discharges which cause it, the Secretary must obtain the written consent of the Governor of that state..$^{21}$ In any event he must give polluters at least 180 days' notice before initiating abatement action. ${ }^{22}$ There are no reported cases under the Act. Political and personal factors can delay enforcement while pollution continues at a dangerous rate. ${ }^{23}$ Fortumately, the water quality standards promulgated pursuant to the Act may offer an alternative method of control by providing the hitherto missing item necessary for successful private nuisance actions.

\section{II. "Reasonable Use" as a Two-Edged Sword}

Survival of the private nuisance action in the face of the liederal $\mathrm{Act}^{24}$ raises the possibility that the riparian will be subject to incon-

17. 33 U.S.C. $\$ 466 \mathrm{~g}(\mathrm{c})$ (1) (Supp. IV 1969). Water quality standards are of two types: receiving water standards state the required condition of the stream, and cflitent standards specify the required characteristics of wastes to be discharged. 3 WATER AND WATLR Rigir's (R. Clark ed. 1967) $\$ 229.1$, at 234-37. The Federal Act provides for quality criteria (recciv* ing water standards) and enforcement plans (presumably effluent standards).

18. N.Y. Times, April 7, 1969, at 59, col. 2 (noting also that the Secretary of the Interior has taken exception to particular aspects of the standards in various states).

19. For a complete exposition of the enforcement mechanism of the Act, sec 3 WATEK AND WATER RIGHS, supra note $17, \S 248$, at $981-404$.

20. 33 U.S.C. $\S 466(\mathrm{~g})(\mathrm{c})(5)$ (Supp. IV 1969) as it authorizes action under $\$ 466 \mathrm{~g}(\mathrm{~g})(1.2)$ (Supp. IV 1969).

21. 33 U.S.C. \$ $466 \mathrm{~g}(\mathrm{~g})(2)$ (Supp. IV 1969).

22. 33 U.S.C. \& $466 \mathrm{~g}(\mathrm{C})(5)$ (Supp. IV 1969) as it authorizes action under \& $466 \mathrm{~g}(\mathrm{~g})(2)$ (Supp. IV 1969).

23. The following colloquy, relating to enforcement under an earlier verslon of the Act, is illustrative.

Senator Muskie. Now, with respect to the decisionmaking, what factors must you submit to justify an enforcement action?

Mr. Stein [Chief Enforcement Officer of the Federal Water Pollution Control $\Lambda$ d. ministration]. Well, I think the factors are: one, the situation of pollutions; aftel secondly, what we would determine would be the reaction of the State water pollution control officials. ...

Senator Muskie. So you really supply them with two sets of facts-one on the merits of the case, and two, on the political climate?

Mr. Stein. Yes-in the broad sense-yes, sir.

Hearings on S. 649, stpra note 4, at 81. Similar problems have strangled enforcement by state agencies.

The non-enforcement problem is rooted in the essential unwillingness of the control agency to bring the full force of the enforcement procedure to bear on the polluter. Hines, supra note 5 , at 227.

24. As a part of state substantive law, common law nuisance actions survive the $A$ ct. The Act states: 
sistent rules of substantive law; judicial disregard of the standards set under the Act would leave riparians uncertain of their responsibilities. On the other hand, voluntary adoption of the standards by courts would achieve a desirable uniformity of substantive law.

The guidelines for the determination of water quality standards require the proper authority to engage in the same balancing process that is appropriate to the private nuisance action:

Standards of quality ... shall be such as to protect the public health or welfare, enhance the quality of water, and serve the purposes [of this Act]. . . In establishing such standards the Secretary, the Hearing Board, or the appropriate State Authority shall take into consideration their use and value for public water supplies, propagation of fish and wildlife, recreational purposes, and agricultural, industrial, and other legitimate uses.25

To foster its objectives, the Act requires basin-wide allocation plans. Each riparian is permitted to dispose of an amount of waste suited to the demands of his activity and to the capacity of the watercourse. Thus, built into the water quality standards is a weighing of the social value of competing riparian uses and of the suitability of these uses to the particular watercourse. While the Sanderson court foresaw that the "general health and well-being of the community" might require affirmative steps to abate pollution, it shirked the difficult job of balancing necessary to determine what is "reasonable use."26 The water quality standards embody precisely this balancing by setting, as to each riparian, a maximum level beyond which all pollution is impermissible.

Acceptance of the Federal water quality standards as relevant to a determination of the reasonableness of a polluter's discharge would mise the question of the procedural effect to be given to proof by the plaintiff that the defendant has caused water quality to fall below the minimum prescribed by the standards. By analogy with per se negligence the standards might be given conclusive effect. ${ }^{2 i}$ Other riparians (at least as members of the general public) are certainly among those intended to be protected from the defendant's conduct, and the in-

Nothing in this Act shall be construed as impairing or in any manner affecting any right or jurisdiction of the States with respect to the waters (including boundary waters) of such states.

33 US.C. \$ 466(c) (Supp. IV 1969).

25. Id. \& $466 \mathrm{~g}(\mathrm{c})(3)$.

26. See p. 104 supra.

27. The Restatement of ToRIs offers criteria for the adoption of legislative or administrative standards as per se standards of conduct in tort actions and sugsests that the criteria are applicable to nuisance as well as to negligence. RESTATEasevr (SECOND) of TORTS $\$ 286(1965)$. 
jury is of the type contemplated by the statute in that the defendant's activity is infringing upon other uses found to be legitimate and deserving of protection.

But the legislative history of the Act shows that the water quality standards should not be given conclusive effect in a private action." ${ }^{26}$ Even in official proceedings under the Act, a court must give "due consideration to the practicability and to the physical and economic feasibility of securing abatement of any pollution proved. . . ."20 Senator Muskie, Senate sponsor and floor manager of the bill, agreed during Senate debate that a court must rule on the "reasomableness" of the standards. ${ }^{30}$ In a common law nuisance suit, then, the watex quality standards should be admitted not as evidence of a per se tort, but rather as one very important factor in the determination of rea. sonable use. ${ }^{31}$

Perhaps the most effective use of the standards would be for a court to rule that a prima facie case is established upon a showing that the defendant has exceeded the waste disposal limits imposed by the Act. The polluter would then have to offer compelling considerations to justify his invasion of the rights of other riparians in disregard of stated public policy ${ }^{32}$ Reference to the water quality standards would shilt the focus of discussion from the reasonableness of defendant's use in terms of industry practice to the reasonableness of defendant's use in terms of a comprehensive allocation of water rights among legit.

28. S. Rep. No. 10, 89th Cong., 1st Sess. (1965) stated that "it is not the standards themselves but abatement orders consistent with such standards which are cnforcible." $I d$. 10. Judicial determination in a private action that the standards were not reasonablo would not affect the validity of those standards in a subsequent action brought at the request of the Secretary of the Interior. Cf. 3 WATER AND WATER Rigirs, \$ 428.2(G), supra note 17, arguing that the standards, operating as both state and federal law, are subject to conflicting judicial rulings. The book dismisses the possibility of private actions brought under the Act without reaching the problem of the appropriateness of the standards to common law tort actions.

29. 33 U.S.C. $\$ 466 \mathrm{~g}(\mathrm{~h})$ (Supp. IV 1969).

30. Mr. Miller. At that stage [court action] of the proceeding, it would be proper for the person aggrieved and the person against whom the abatement action is bcing brought to argue the reasonableness of the standards under which the abatement action had been taken. Mr. Muskie. Precisely.

111 Cong. Rrc. 1507 (1965).

31. A court may do so by taking judicial notice of the standards.

Many cases have recognized that a Court may take judicial notice of the rules, regulations and orders of administrative agencies issued pursuant to their delcgated authority.

Int'l Bhd. of Teamsters v. Zantop Air Transp. Corp., 394 F. 2d 36, 40 (6th Cir. 1968), 32. The Act states:

The purpose [of this Act] is to enhance the quality and value of our water resources and to establish a national policy for the prevention, control, and abatcment of water pollution.

93 U.S.C. § 466(a) (Supp. IV 1969). 
imate users. The riparian plaintiff would no longer face nearly insuperable obstacles in his attempt to show that he has been unreasonably harmed.

\section{The Statute and the Remedy Problem}

To abate pollution is more difficult than to recover damages, and monetary damages are in any event inadequate if the private nuisance action is to prove an effective control on pollution. But to secure an injunction, the injured riparian must convince the court not only that a nuisance exists but also that an injunction is the appropriate form of relief. As an equitable remedy, an injunction is generally available only when no adequate remedy exists at law. The legal remedy tends to be insufficient in nuisance actions, since, by nature, the offense is likely to be repeated. To require an injured riparian to bring a series of actions is thought to impose too onerous a burden upon him, ${ }^{33}$ and to limit the injured riparian to compensation by damages is to permit the polluter to condemn another's property for private use.

Even when compensation by damages is manifestly inadequate, however, the "comparative injury" doctrine may operate as a significant restriction upon the willingness of the courts to issue injunctions. Under this doctrine, the court must weigh the harm which would be caused to the plaintiff by failure to issue an injunction against the costs which its issuance would impose upon the defendant and the public interest. ${ }^{34}$ In Carp Pond Co. v. River Basin Paper Co. ${ }^{35}$ for example, the court found the defendant's use of a stream to be unreasonable but refused to issue an injunction. The defendant's investment was fifteen million dollars while the plaintiff's was only ten thousand dollars. The Court based its decision on the ground that "the granting of [an injunction] will work a great injury, entirely

33. Clark, Water Pollution Law in Idaho, I IDAHO L. REv. 111, 123 (1964).

34. This second-Ievel balancing takes place only after the defendant's activity has been found to constitute a nuisance. It concerns the form of relief rather than the plaintiff's right to relief. See Clifton Iron Co. v. Dye, 87 Ala. 468 (1888); 1 HANpEx \& JAMEs, supra note $6, \S 1.30$, at 90-91; Maloney, The Balance of Convenience Doctrine in the Southeastem States, Particularly as Applied to Watcr, 5 S.C.L.Q. 159, 160.67 (1959); Note, $A$ Survey of Common Law Remedies for Stream Pollution in New York, 10 BuFfALo L. REv. 484, 488 (1961); Note, Statutory Trealment of Industrial Stream Pollution, supra note 5, at 309-10. Cf. Borough of Westville v. Whitney Home Builders, 10 N.J. Super. 62, 122 A.2d 233 (1956).

35. 240 Mich. 279, 215 N.W. 825 (1927). 
disproportionate to that sustained by plaintiff, upon the defendants, and that it will also seriously effect the prosperity of the city."so

Some courts, however, have rightfully repudiated the notion that the greater size of a defendant's operation gives him a preponclerance of equity over the plaintiff because "if followed to its logical conclusion, [it] would deprive the poor litigant of his property by giving it to those already rich." 37 Moreover, the promotion of industrial growth and the protection of jobs presumably found to constitute the "public interest" by the Carp court are today only part of a "public interest" which is more broadly defined. The growing realization that our resources are limited gives the public a clear stake in water quality. The public has an interest not only in the continued operation of the polluter's factory but also, and just as properly, in the manner of its operation. The Federal Act has given concrete expression, to this broadened public interest; ${ }^{38}$ if the operation of a factory creates pollution in excess of the negotiated permissible levels, the public interest in water quality ought now to be considered in favor of en. joining the excess pollution.

The technical complexity attending the issuance of injunctions must also have contributed to the unwillingness of courts to grant such relief in water pollution actions. ${ }^{32}$ Short of closing down a factory, an injunction must specify the maximum permissible amount of pollution and allow the polluter a reasonable time in which to reduce his discharge below the maximum. ${ }^{40}$ The Federal Act could now facilitate the issuance of these necessarily complex injunctions. Basin-wide plans, specific as to poundage amounts of chemical pollutants, are being developed to allocate waste-carrying capacity among riparian owners. A court might well utilize the appropriate portion of a plan in framing an injunction intended to prevent a polluter from discharging more than his fair share of waste into a watercourse.

Even when legislative means of enforcement prove ineffective, riparian owners may help to abate pollution through private nuisance actions by drawing upon the public policy and the concrete standards of the Federal Water Quality Act.

36. Id. at 289,215 N.W. at 328 .

37. Whalen v. Union Bag and Paper Co., 208 N.Y. 1, 5, 101 N.E. 805 (1913); accord, c.G., Weston Paper Co. v. Pope, 155 Ind. 394, 57 N.E. 719 (1900).

38. See note 29 supra.

39. See Hanks, supra note 5, at 669.

40. The lack of appropriate abatement technology increases the equitics on the tide of the polluter, although arguably the lack of pressure on polluters is a primary rctson for the primitive state of technology. The proper authority will take the state of technology into account in setting effluent standards. Thus the standards themselves represent is resolution of the polluter's equities. 